\title{
Magnetic Characterization of the Carajás Mineral Province, Brazil
}

\section{Yasmim Monteiro Cordeiro, Gleyton Pinto Lisboa, Vinny Sales Esterque, Hans Schmidt Santos, Larissa Santos de Paula, Orlandemberg Pereira Silva}

Faculdade Salesiana Maria Auxiliadora (FSMA), Macaé, Brazil

Email: hans.schmidt@live.com

How to cite this paper: Cordeiro, Y.M., Lisboa, G.P., Esterque, V.S., Santos, H.S., de Paula, L.S. and Silva, O.P. (2020) Magnetic Characterization of the Carajás Mineral Province, Brazil. Open Access Library Journal, 7: e6356.

https://doi.org/10.4236/oalib.1106356

Received: April 24, 2020

Accepted: May 12, 2020

Published: May 15, 2020

Copyright (๑) 2020 by author(s) and Open Access Library Inc.

This work is licensed under the Creative Commons Attribution International License (CC BY 4.0).

http://creativecommons.org/licenses/by/4.0/

\begin{abstract}
This work presents the magnetometric method application in the Carajás Mineral Province, located in the south of the Pará state, Brazil. This is a region rich in iron ore in hematite form distributed in the Itacaiúnas Belt. The available gross magnetometric data were corrected and subtracted from the IGRF (International Geomagnetic Reference Field). Subsequently, magnetic anomaly, vertical derivative, horizontal derivatives and analytical signal maps were made that allowed to identify the main faults and the geological bodies of the region.
\end{abstract}

\section{Subject Areas}

Environmental Sciences, Geology, Geomorphology, Geophysics

\section{Keywords}

Magnetism, Magnetometric Method, Carajás, Iron Ore

\section{Introduction}

The Earth's lithosphere is made up of rocks that contain some amount of magnetic minerals. Two types of magnetization are considered, the primary and the secondary. In the formation of rocks, the constituent magnetic minerals acquire a magnetization parallel to the Earth's magnetic field, providing direction and intensity information of the magnetic field at the time the rock was formed which is called primary magnetization. However, rocks can still acquire magnetization after their formation due to physical and chemical processes. This type of magnetization is called secondary remnant magnetization [1].

According to Agrella Filho (2009) [2], in rocks, only a small part of the minerals contributes to magnetism. The type of magnetic mineral, the size of the 
grain, its magnetic anisotropies, and the manner in which it has acquired a remnant magnetization are the most important factors affecting the magnetism of rocks.

The most common rock constituent minerals have a very low magnetic susceptibility and thus the magnetic characteristic of the rocks is due to the small proportion of magnetic minerals they contain [3].

The investigation of the magnetic field related to the magnetization of the Earth's crustal rocks can yield important data on subsurface structures and thus help the prospecting of important magnetic minerals such as Iron [4].

The Brazil-Canada Geophysical Project (BCGP) 1020 series was born from an agreement between the National Department of Mineral Research (NDMR), the Ministry of Mines and Energy (MME) and the Canadian International Development Agency (CIDA). This project provided a large amount of magnetic data covering the Carajás Iron Mineral Province, which will be used for study in this paper and can thus contribute to a better characterization of iron ore deposits formed mainly by hematite $\left(\mathrm{Fe}_{3} \mathrm{O}_{3}\right)$.

Thus, Section 2 of this paper describes the general characteristics of the Carajás Province as location, topography and land use. Section 3 addresses the Materials and Methods describing the methodology and theoretical concepts. Section 4 discusses the data processing and the main results in this paper. Finally, Section 5 brings together the main final considerations.

\section{Carajás Province}

The Carajás Mineral Province is located in the municipality of Parauapebas, located approximately $550 \mathrm{~km}$ southwest of Belém, Brazil. This region aroused the interest of mining companies in the mid-1950s due to iron $(\mathrm{Fe})$ deposits, gold $(\mathrm{Au})$, copper $(\mathrm{Cu})$ and other minerals underground. The Araguaia Project pioneered an aerophotogrammetric scan of the region in an attempt to assess its mineral potential [5].

The iron deposits located north of the Carajás mountain are part of the deposits belonging to Companhia Vale do Rio Doce (CVRD), one of the companies responsible for the region's mining process (Figure 1) [6].

\subsection{Geology of the Carajás Mineral Province}

The Carajás Mineral Province is considered the main mineral province of Brazil and comprises important deposits of $\mathrm{Fe}, \mathrm{Au}, \mathrm{Cu}, \mathrm{Mn}$ and other metals, representing one of the highest concentrations of ores on the planet. This locality was generated, reactivated and tectonically stabilized in the Archean period and only in the Paleoproterozoic period was affected by an extensive event accompanied by anorogenic granitic intrusions and associated dykes [8].

\subsection{Topography of the Mineral Province of Carajás}

A topographic map of the Carajás region was generated. It shows the topography 
of the terrain and indicates that, in most of the basin, the altitude varies from approximately 150 meters (cyan part of Figure 2) about 650 meters in the midwestern portion of the province (magenta part of Figure 2).

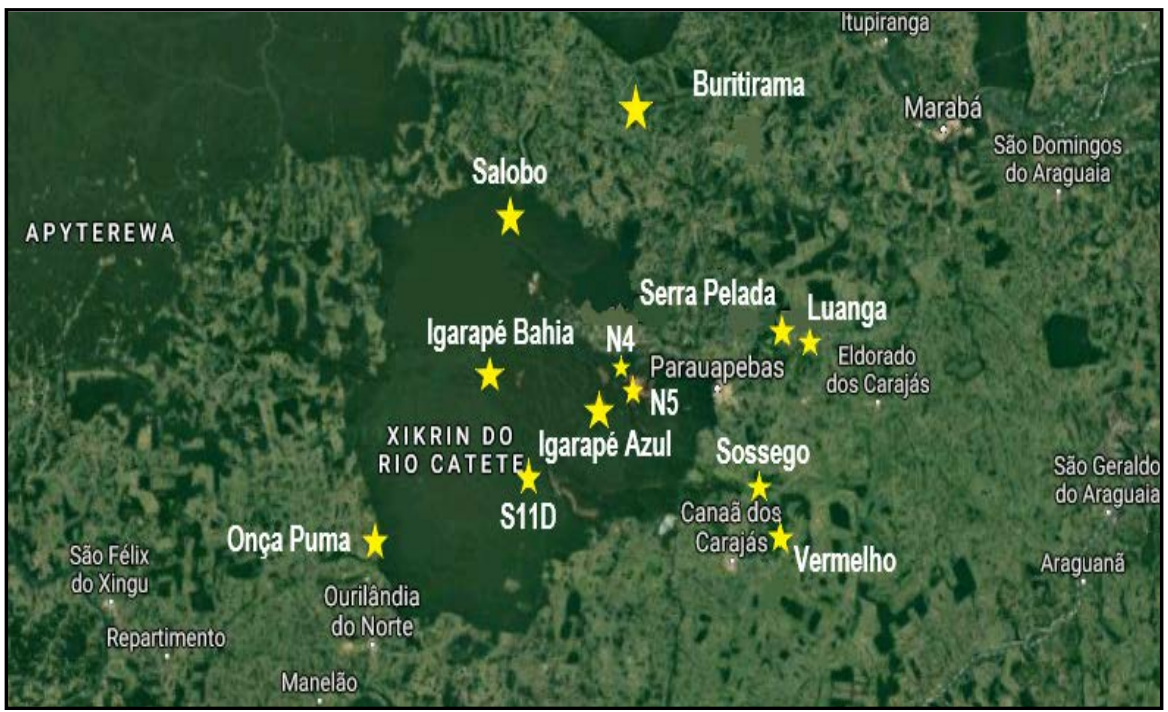

Figure 1. Satellite image of the mineral deposits of the Carajás Mountains. Adapted from [7].

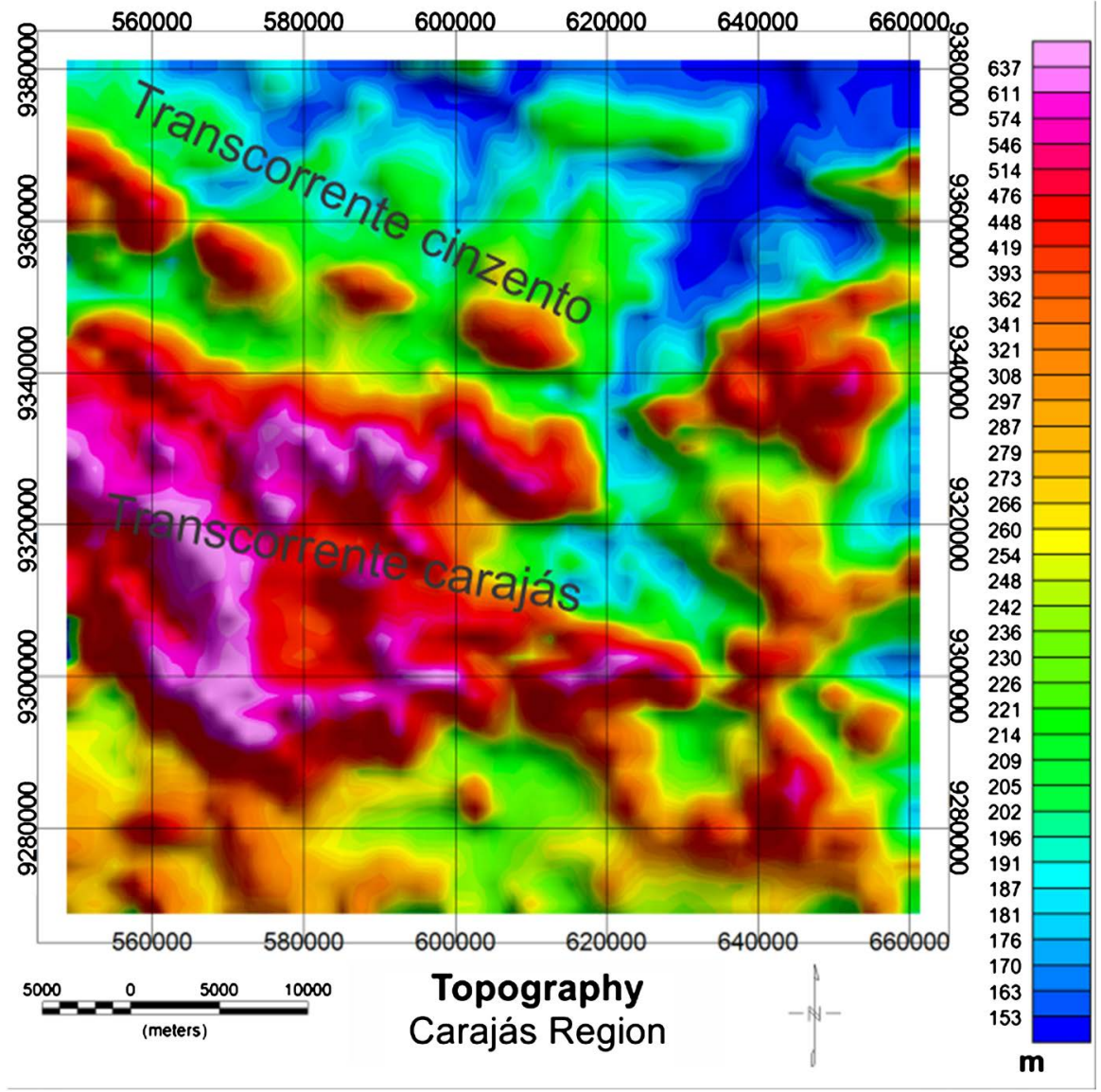

Figure 2. Topography of the Carajás Mineral Province made from Topex 18.1. 


\section{Materials and Methods}

A research of applied nature was performed, because the generated knowledge can be used in a practical application such as support in the search for new sources of iron ore.

As for the goals, this is an exploratory research, because the magnetic maps obtained can broaden the knowledge of the region and are useful for the planning of new research of mineral resources.

As for the approach, this is quantitative research, as the obtained maps are quantified in $n T$ or $n T / m$. But it is also a qualitative research as it allows to assess the local geology based on the magnetic data.

As for the procedures, it is a bibliographic and experimental research. Bibliographic research is carried out emphasizing the study of magnetometry and magnetic minerals, the acquisition of magnetic data and their applications and the processing of magnetic data by consulting books, scientific articles and websites.

The present work is also about experimental research, since variables such as interpolation cell size, sampling window and filter applications can set up the cause (geology of the region) and the effect (magnetic field measured on the magnetometer used in the aircraft). Through this relationship, practical results are deduced as determining the coordinates of the highest analytical signal values associated with geological materials in the region.

The analytical signal is the method used to locate the magnetic source, without the need to encompass the remaining magnetization. The analytical signal amplitude can be performed at low altitudes, unlike other techniques which generally fail in these regions. From the combination of vertical and horizontal gradients, the amplitude of the analytical signal is formed (Equation (1)) [9].

$$
\left|A_{(x, y)}\right|=\sqrt{\left(\frac{\partial T}{\partial x}\right)^{2}+\left(\frac{\partial T}{\partial y}\right)^{2}+\left(\frac{\partial T}{\partial z}\right)^{2}}
$$

where $T$ is the magnetic field anomaly and $\left(\frac{\partial T}{\partial x}\right),\left(\frac{\partial T}{\partial y}\right)$ and $\left(\frac{\partial T}{\partial z}\right)$ are the horizontal derivatives at $x, y$ and $z$ respectively.

\section{Processing and Results}

\subsection{Data Collection}

Data from the Brazil Canada Geophysical Project (PGBC 1020) were collected by Douglas DC-3 aircraft with the Digital Gulf Mark IIID Fluxgate magnetometer, which covered most of the province, divided into two parts: phase $1(2 \mathrm{~km}$ of flight line spacing) and phase 2 (1 km flight line spacing) (Figure 3 ).

\subsection{Image Processing}

To obtain the location of the crust magnetic sources, it was necessary to isolate the crust magnetism (magnetic anomaly) by removing the core magnetic field 


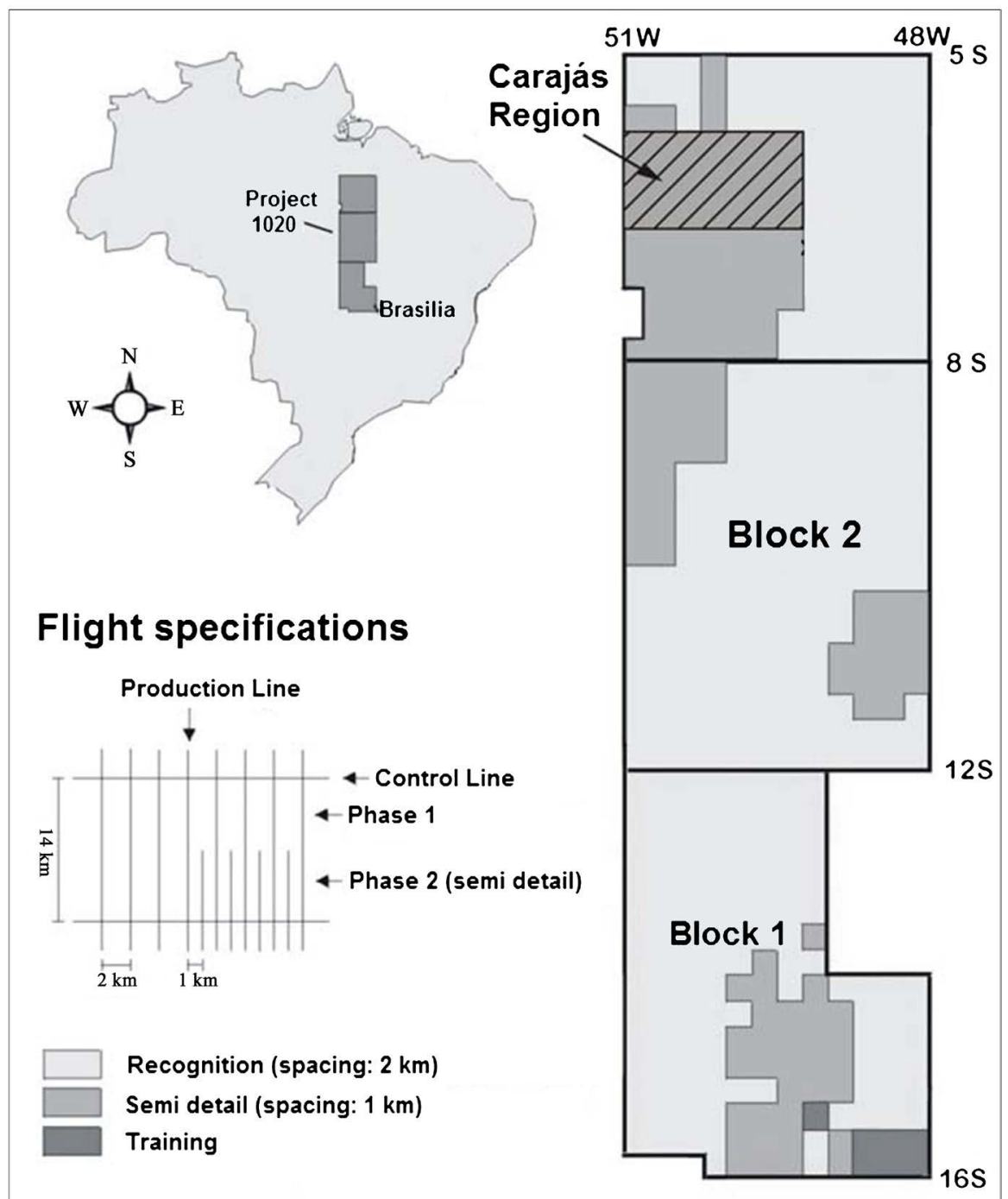

Figure 3. PGBC-1020 aerogeophysical project, highlighting the Carajás region in the Block [10].

(IGRF) from the values measured by the magnetometer. After that, the horizontal and vertical derivatives of the magnetic field were calculated and the combination of these derivatives allowed to obtain the analytical signal of the magnetic field that located the main magnetic sources.

\subsubsection{Obtaining IGRF}

The core magnetic field is in the order of thousands of nT. This field can be well estimated by mathematical models called the International Reference Geomagnetic Field (IGRF).

For the generation of the IGRF, 144 points were used to the studied region surface in latitudes and longitudes on the UTM (Universal Transverse Mercator) scale. These locations were used to calculate the total magnetic field strength $(\mathrm{F})$ of the respective positions studied using the "Magnetic Field Calculator" available on the Government of Canada's Natural Resources Canada website 
(https://www.geomag.nrcan.gc.ca/calc/mfcal-en.php).

With the IGRF total field data obtained, the grid for correction was calculated for the entire region through minimal curvature interpolation and $2500 \mathrm{~m}$ cells. The result shown in Figure 4 illustrates the magnetic field of the Earth's core at the time of the survey.

\subsubsection{Obtaining the Magnetic Anomaly}

Generally, the raw data is a sum of the core magnetic field, the influence of the external magnetic field and the crust magnetic field, the latter being what really matters for the analysis in question, but for the data collected for this work, the values for the external magnetic field had already been subtracted, facilitating the image processing. Thus, the raw magnetic field visualized before corrections follows in Figure 5.

The magnetic anomaly was obtained by subtracting the core magnetic field values, thus remaining only the crust magnetic field data, which is required to obtain the Magnetic Anomaly map through Equation (2).

$$
\mathrm{AMF}=\mathrm{MF}-(\mathrm{EMF}+\mathrm{IGRF})
$$

where:

- $\operatorname{AMF}($ Anomalous Magnetic Field $)=$ Anomalous Magnetic Field

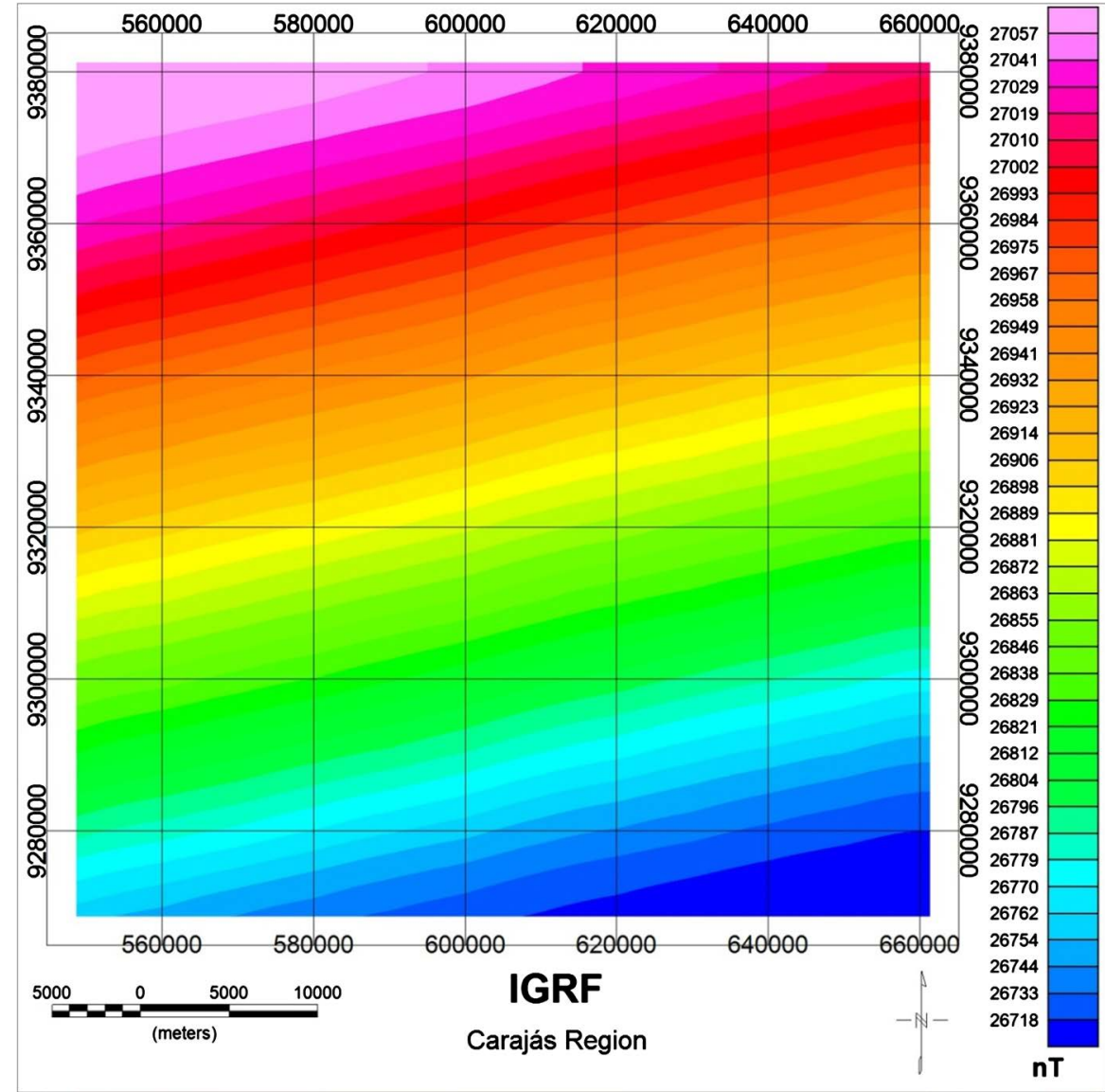

Figure 4. IGRF Map. 


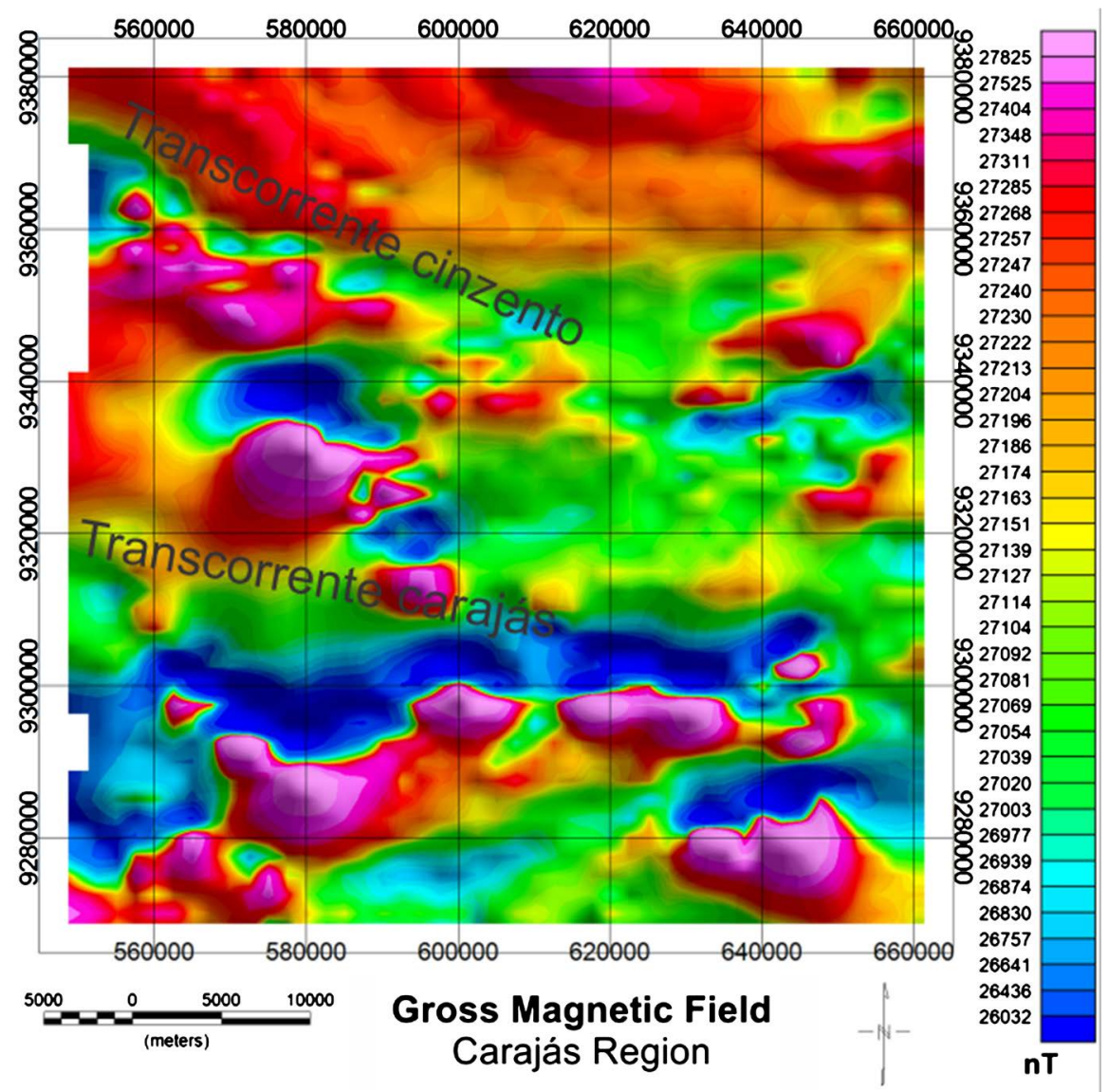

Figure 5. Gross magnetic field.

- $\operatorname{MF}($ Measured Field $)=$ Measured Field

- EMF (External Magnetic Field) = External Magnetic Field (sources outside the planet).

- IGRF (International Geomagnetic Referential Field) = International Reference Geomagnetic Field.

Thus, with the aid of Equation (2) and the IGRF data, a map of the magnetic anomaly reflecting the crust magnetism in the province of Carajás was obtained through interpolation by minimum curvature with 250 meters cell (Figure 6).

This map reflects the crustal magnetism of the region and the comparing with the map of Figure 7 shows the region known as "Carajás Failure" and the entire region with the presence of "black spots", i.e. the region of the Grão-Pará group that has the highest level of magnetism in the region, which explains the presence of many faults (black lines).

\subsubsection{Obtaining Analytic Signal of Magnetic Field}

The horizontal $\left(0^{\circ}\right.$ and $\left.90^{\circ}\right)$ (Figure 8 and Figure 9) and vertical derivative (Figure 10) gradient maps can amplify the short wavelengths and attenuate the long wavelengths of the magnetic signal in the three orthogonal directions, highlighting the edges and contacts of geological features and faults. These prove the fact that the location of the highest failure rate (rupture or scission regions of 


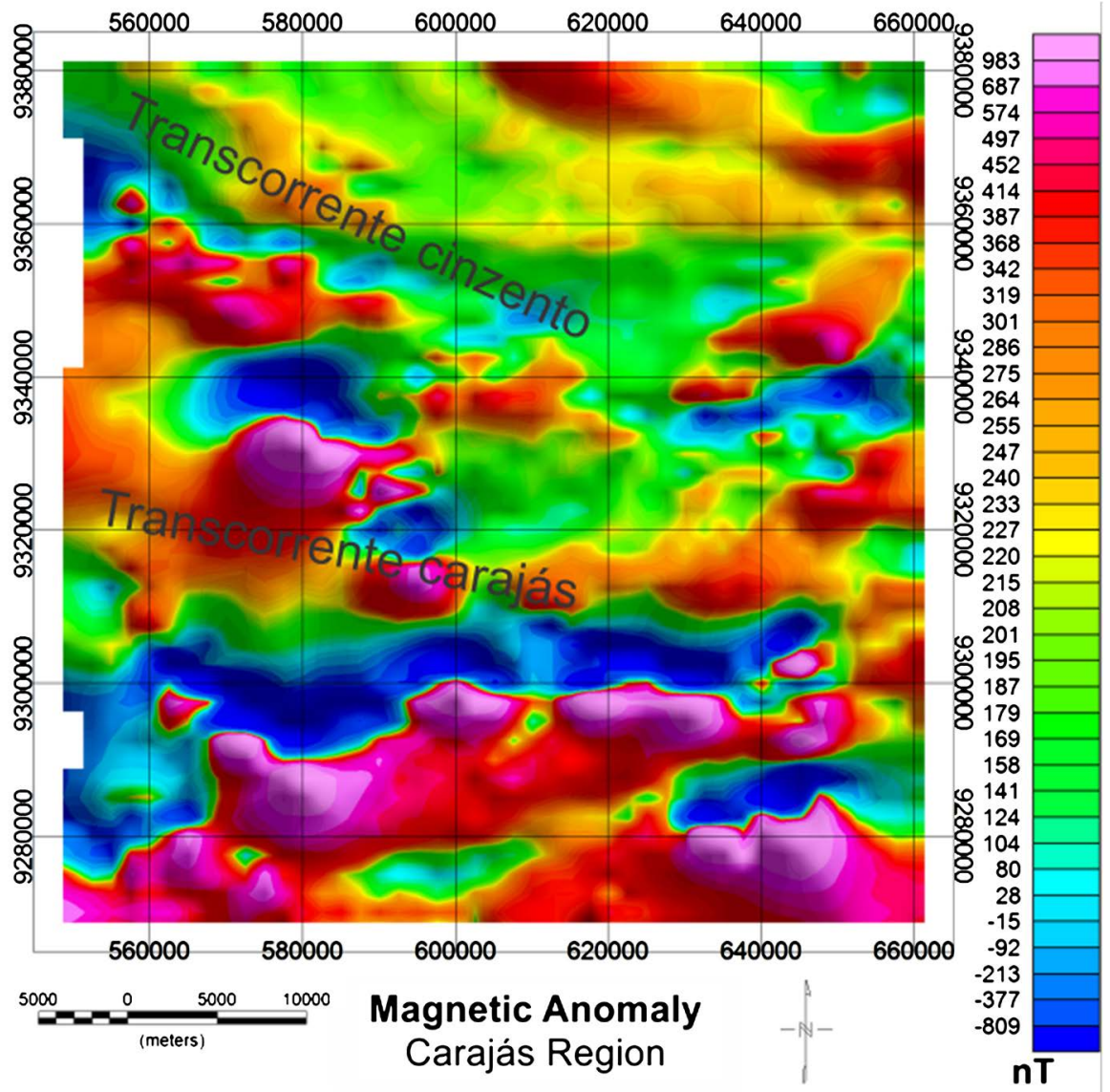

Figure 6. Magnetic anomaly map of the Carajás Province.

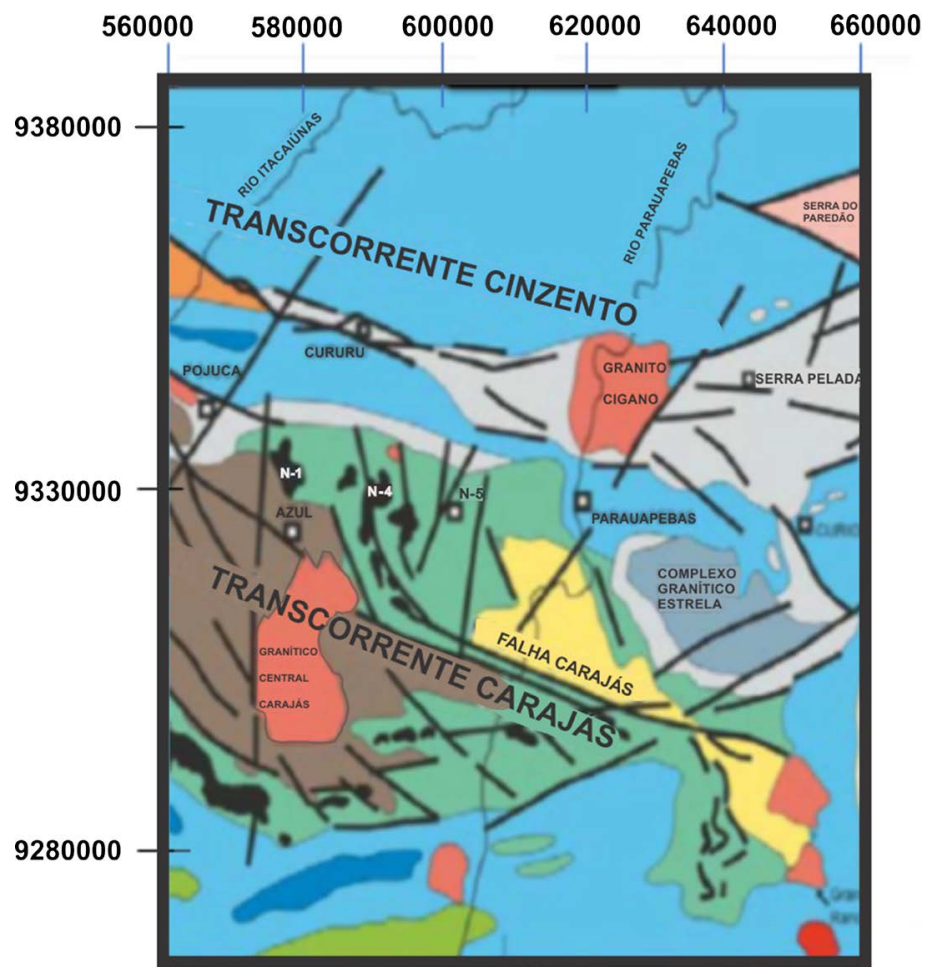

Figure 7. Geological map of the Itacaiúnas [10]. 


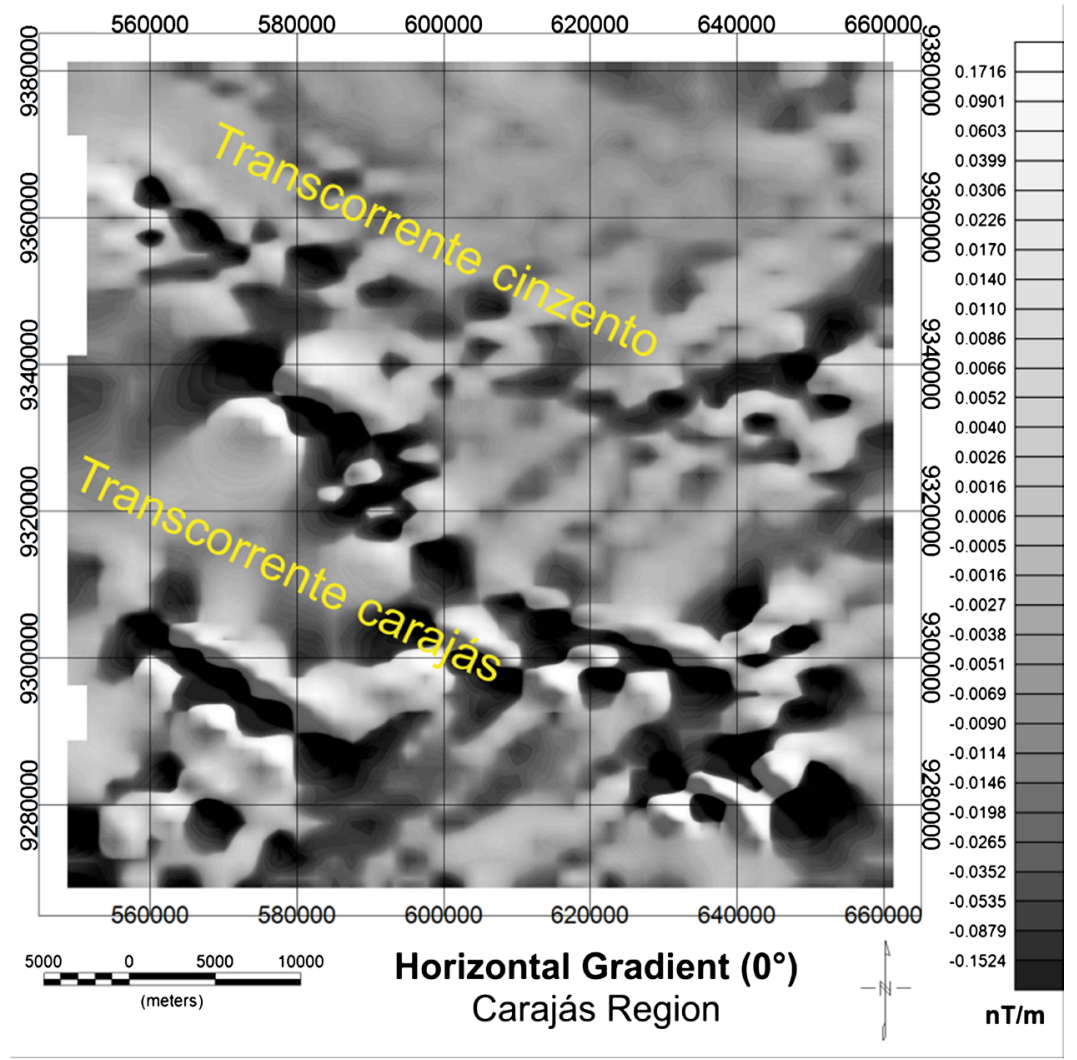

Figure 8. Horizontal gradient $\left(0^{\circ}\right)$.

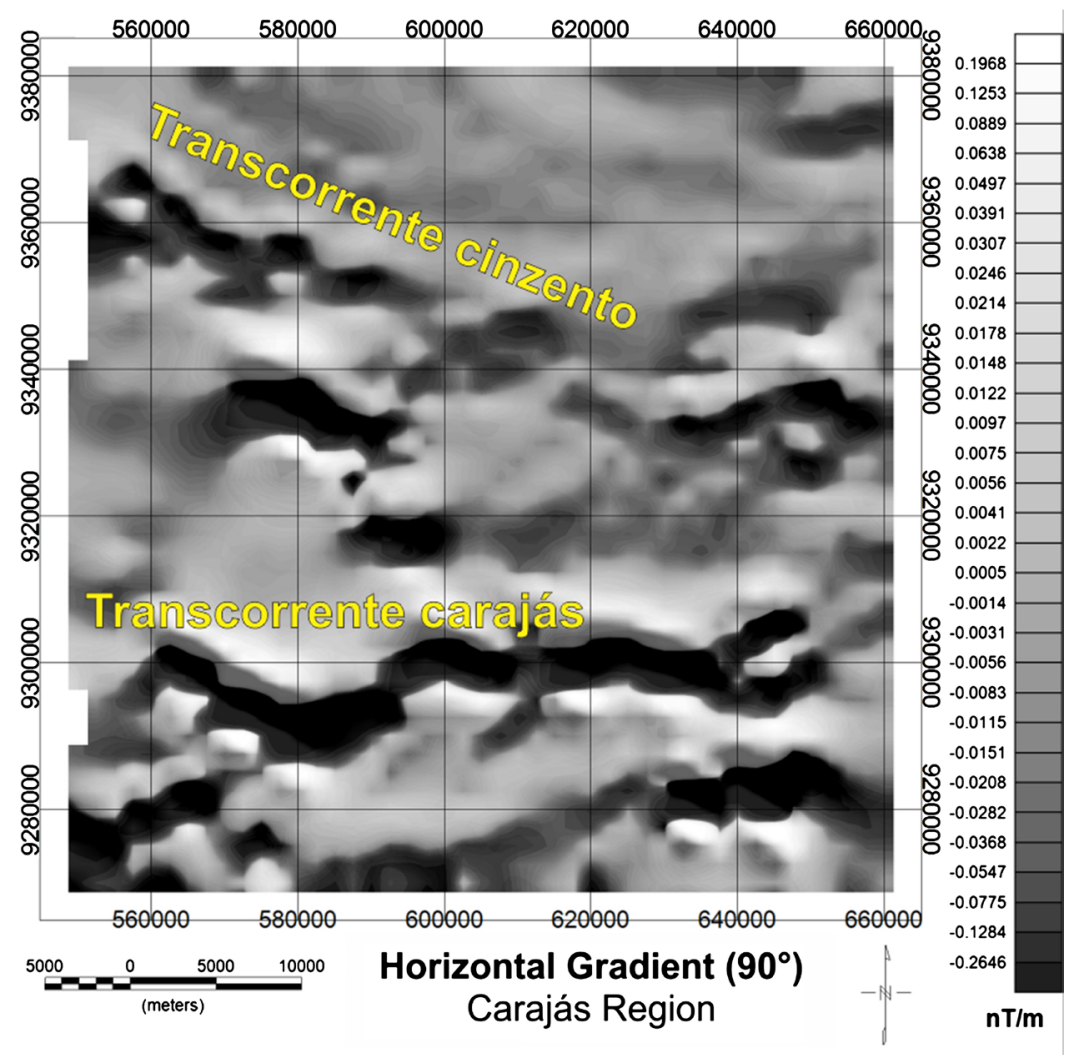

Figure 9. Horizontal gradient $\left(90^{\circ}\right)$. 


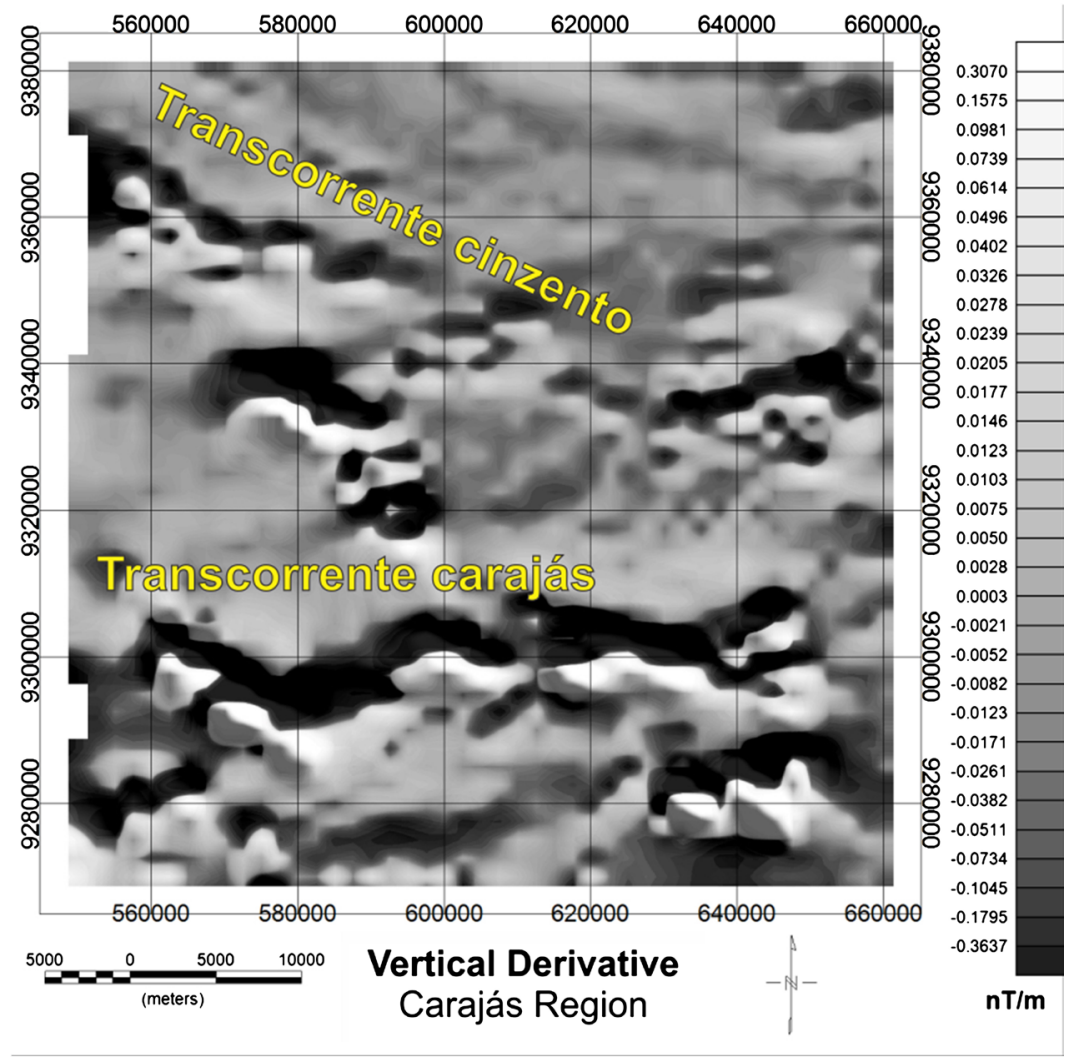

Figure 10. Vertical derivative.

rock blocks or narrow surface bands) is in the locations mentioned above.

In addition, the horizontal and vertical derivative maps allow to identify the main lineaments of the Carajás Mineral Province, which presented preferential east-west direction and were more expressive in the south and north map area. These lineaments are mainly expressed by magnetic ridges and abrupt changes in the magnetic gradient and are compatible with the black lines in Figure 7 that indicate the region's fault regions.

The combination of the three derivatives gives the amplitude of the analytical signal (Figure 11) according to Equation (1).

The location of major anomalies is confirmed by the amplitude map of the analytical signal that reflects the maximum of magnetic contacts regardless of the magnetization direction. The map effectively shows the magnetic bodies associated with major failure events.

According to Figure 11, the main magnetic sources shown in magenta were precisely located. These locations are in the region of the Grão Pará Group (one of the subdivisions of the Itacaiúnas supergroup) which consists of a volcanic sedimentary sequence formed by basalt spills superimposed on jaspilites, which host high-grade iron ores ( $>65 \% \mathrm{Fe})$, formed by hematites. These magenta regions presented the highest analytical signal, and a variation of close to $1 \mathrm{nT}$ was calculated for each meter associated with the failures of the region and the iron ore producing regions. 


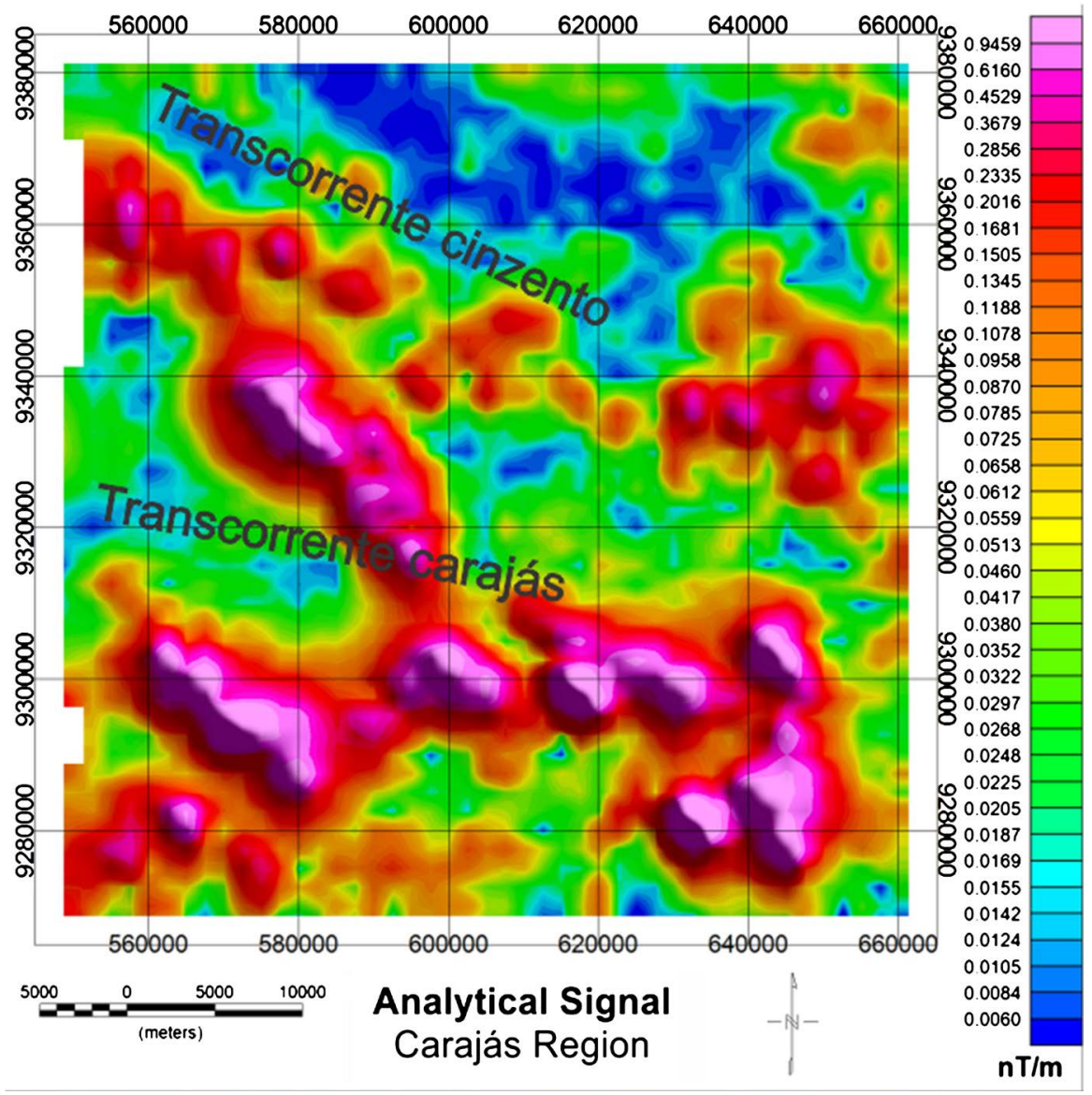

Figure 11. Analytical signal map.

Figure 7 shows that where there are black spots (iron ore producing regions) on the Carajás geological map, there is a strong analytical signal (Figure 11). In the Mineral Province of Carajás, they are different types of iron ore, whose nomenclature is associated with their industrial use and their physical properties. The main types are: 1 ) hematite; 2 ) itabirites or jaspilites; 3 ) "canga" - superficial material (with significant levels of iron and phosphorus).

Finally, with topography analysis, it can be seen that the fields with the highest level of magnetism are found in the mountain peaks of the province.

\section{Conclusions}

Iron ore present in the Carajás Mineral Province is highly relevant not only for the quantity present in this region but also for the excellence in its quality. This fact validates the need to always be researching the geology of the region.

In possession of the magnetometric data, it was possible to study the geomorphological features in the lands that cover the Carajás Mineral Province. The maps obtained were compared and correlated with topographic and geological maps of the region.

In general, the largest magnetic measurements were found in the higher altitude regions which are in the Itacaiúnas supergroup region. The lowest counts 
were found on the banks of and around Parauapebas rivers and in the Águas Claras Formation, formed by marine to fluvial sedimentary rocks.

Finally, the set of maps obtained provides a general magnetic base that can be used in other studies such as geological, geochemical and environmental, contributing to the knowledge of the soil and subsoil of Carajás Mineral Province and surroundings.

\section{Conflicts of Interest}

The authors declare no conflicts of interest regarding the publication of this paper.

\section{References}

[1] Garcez, A.G. (2013) Magnetismo das Rochas. Um Curso de Geofísica. Cefet Química, Rio de Janeiro.

[2] Agrella Filho, M.S. (2009) Minerais Magnéticos. Instituto de Astronomia e Geofísica, São Paulo.

[3] Kearey, P., Brooks, M. and Hill, I. (2002) An Introduction to Geophysical Exploration. Blackwell Ltd., Oxford, England.

[4] Lowrie, W. (2007) Fundamentals of Geophysis. 2nd Edition, Swiss Federal Institute of Technology, Cambridge University Press, Zürich.

[5] Teruiya, R.K. (2003) Integração Digital de Dados Multifontes no Estudo Geológico do Granito Cigano, Província Mineral de Carajás-PA. Dissertação de Mestrado, São José dos Campos.

[6] Zucchetti, M. (2007) Rochas máficas do grupo grão Pará e sua relação com a mineralização de ferro dos depósitos N4 e N5, Carajás-PA. Tese Doutorado, Universidade Federal De Minas Gerais Instituto De Geociências Programa De Pós-Graduação Em Geologia, Belo Horizonte, Minas Gerais, Brasil.

[7] Silva, A.F. (2013) Serra dos Carajás-Recursos Minerais. Universidade Federal do Pará.

[8] Galarza, M.A. and Macambira, M.J.B. (2002) Geocronologia E Evolução Crustal Da Área Do Depósito De Cu-Au Gameleira, Província Mineral De Carajás (Pará), Brasil. Laboratório de Geologia Isotópica, Pará-Iso, Centro de Geociências, UFPA. https://doi.org/10.5327/S1519-874X2002000100012

[9] Ribeiro, J.D., Queiroz, I.M.S. and Santos, H.S. (2015) Depth Basement Estimate of the Alto Xingu Subbasin, Brazil. International Journal of Engineering Sciences \& Emerging Technologies, 75, 725-736.

[10] Carneiro, C.C., et al. (2006) Fusão de Imagens Altimétricas e Aeromagnetométricas como Ferramenta de Interpretação Geológica, exemplo da Província Mineral de Carajás (PA). Revista Brasileira de Geofísica, 24, 261-271.

https://doi.org/10.1590/S0102-261X2006000200009 